УДК 37.013.016:91](477.83)

ГЕОГРАФІЧНА ОСВІТА У ЛЬВІВСЬКІЙ ОБЛАСТІ

\author{
Марія Лаврук \\ Львівський начіональний університет імені Івана Франка, \\ вул. П. Дорошенка, 41, 79000, м. Львів, Україна, \\ e-mail: lavruk.maria@gmail.com
}

\begin{abstract}
У контексті реформування в Україні загальноосвітньої і вищої школи географічну освіту регіону та країни загалом доцільно розглядати як систему, яка охоплює початковий, базовий, допрофесійний і професійний рівні. Наразі немає загальної картини стану і тенденцій розвитку різних сегментів географічної освіти у Львівській обл., які необхідно враховувати для вироблення регіональної освітньої політики. Названо кількісні показники суб'єктів навчального процесу з географії на різних освітніх рівнях і в територіальному розрізі. Виявлено, що найближчі п'ять років найліпшу перспективу щодо кількісних показників розвитку матиме базова географічна освіта, що зумовлено порівняно сприятливою ситуацією з кількістю учнівського контингенту в молодшій школі регіону. Детально схарактеризовано освітні здобутки школярів Львівщини з географії на всеукраїнському рівні, зазначено центри оптимального розвитку географічної освіти в області, якими є Львів, Дрогобич, Самбір, Стрий, Червоноград, науково-методичний доробок учителів географії регіону. Проаналізовано суперечливу тенденцію між кількісним зростанням професійного сектора географічної освіти (відкриття в регіоні нових університетських кафедр) та потребами загальноосвітньої школи у фахівцях, між соціально зумовленим обмеженням працевлаштування молодих фахівців і зростанням частки пенсіонерів серед учителів географії. 3'ясовано, що в освітній галузі не проти працювати $65 \%$ студентів-випускників географічного факультету ЛНУ імені Івана Франка, які можуть за п’ять-сім років замінити всіх учителів географії регіону передпенсійного і пенсійного віку. Відсутність ефективної освітньої політики на державному і регіональному рівнях унеможливлює поповнення шкільного сегмента географічної освіти молодими фахівцями, що сповільнює процес модернізації освіти і реальне іiі реформування.

Ключові слова: географічна освіта, рівні географічної освіти, якість знань з географії, вікова структура вчителів географії, дидактичні здобутки вчителів географії регіону, професійні наміри випускників географічного факультету.
\end{abstract}

У 2016/2017 навчальному році в Україні з переходом загальноосвітніх закладів на програму допрофільного і профільного навчання, а вищих навчальних закладів на триступеневу систему підготовки фахівців, завершиться формування системи освіти, яка включає пропедевтичний, загальноосвітній, допрофесійний і професійний рівні. Такі ж якісні зміни торкаються і географічної освіти, яку донедавна розглядали лише як різновид освіти професійної. 3 огляду на зміни в структурі географічної освіти актуальним $\epsilon$ дослідження кількісних i якісних параметрів іiі функціонування, науковоінформаційних та науково-методичних зв'язків між структурними елементами фахової географічної освіти, які забезпечують реалізацію освітньої реформи.

Концептуальну модель багаторівневої географічної освіти в Україні та розвитку iii складових розробили відомі географи-науковці і педагоги П. Шищенко, Я. Олійник, О. Дмитрук, О. Топузов, О. Надтока, Л. Вішнікіна, Л. Круглик, М. Криловець та ін. Актуальні публікації у науково-методичних і фахових виданнях присвячені переважно

(C) Лаврук М., 2015 
структурно-змістовим і методичним аспектам нової географічної освіти. Комплексних досліджень стану географічної освіти в регіонах чи у державі загалом практично немає.

Відповідно до принципів неперервності та наступності географічної освіти всі освітні заклади області, у яких вивчають географічні дисципліни, утворюють чотириступеневу функціональну систему. Метою дослідження стало вивчення стану кожної з ланок цієї системи, виявлення територіальних відмінностей у параметрах розвитку географічної освіти у Львівській обл., з'ясування взаємозв'язків і перспектив кожного рівня географічної освіти регіону.

Географічну освіту треба розглядати як підсистему освітньої системи України. Географічний компонент освіти спрямований на засвоєння учнями знань про природу і соціальну складову географічної оболонки Землі, формування в них комплексного, просторового, соціально зорієнтованого знання про планету Земля внаслідок застосування краєзнавчого, регіонального і планетарного підходів та усвідомлення цілісного географічного образу своєї країни.

У контексті реалізації нових державних стандартів загальної середньої і вищої освіти географічна освіта починається в початковій школі, формуючи на пропедевтичному рівні елементи географічних знань, загальні відомості з географії рідного краю та географії України; в основній школі учні здобувають базову середню географічну освіту; у старшій школі - профільну географічну освіту, яка спрямована на майбутню професію; у вищій школі симпатики науки про Землю можуть здобути базову вищу географічну освіту на рівні бакалаврату (засвоєння основ географічної освіти і практики, набуття навичок географічної культури, визначення і вибір географічної спеціальності) або ж повну вищу географічну освіту на рівні магістратури, яка формує наукову спеціалізацію (див. рис. 1).

Географічна освіта в загальноосвітніх школах області: початковий, базовий $і$ профільний piвні. У 2015/2016 н. р. географію в загальноосвітніх школах востаннє викладають за старою програмою, яка охоплює вивчення предмета як базового у 10 класі. Тому кількісний склад учнів, які вивчають цей предмет, ще не доречно структурувати за триступеневою схемою. Водночас урахування кількісних показників розподілу учнів за класами важливе вже нині з огляду на припинення вивчення географії як базової дисципліни в 10 класі, що зумовлює звуження учнівського контингенту в цій сфері та зменшення навантаження вчителів географії.

Станом на 2015/2016 н. p. географію в загальноосвітній школі вивчало 132340 осіб (учні 5-10 класів). П'ятикласників зараховуємо до когорти учнів-географів на підставі того, що предмет “природознавство”, який вони вивчають, містить значний географічний компонент і його викладають переважно вчителі географії.

Уже 2016/2017 навчального року кількість учнів, які вивчатимуть географію як предмет (5-9 класи), становитиме 121709 осіб, що менше майже на 12 тис. порівняно 3 2015/2016 н. р. Проте на найближчі п’ять років учнівський контингент, який вивчатиме географію, кількісно зростатиме й 2020/2021 н. р. становитиме 132516 осіб, що навіть більше, ніж нині, коли географію вивчають ще й десятикласники. Така сприятлива тенденція можлива завдяки більшій кількості школярів у теперішній молодшій школі. Проте зростання очікуване тільки у містах обласного значення.

Територіальний розподіл учнів, які вивчають географію, доволі нерівномірний. В обласному центрі і восьми містах обласного значення зосереджено 42 \% від усіх учнів за- 
гальноосвітніх закладів, які вивчають предмет. Основним центром шкільної географічної освіти регіону є Львів. Тут зосереджено найбільше загальноосвітніх закладів I-II і II-III ступенів усіх типів - 135 (12\% від загальної кількості по області - 1 149), у тім числі 11 гімназій, 7 ліцеїв і 19 НВК. У них навчається понад чверть усіх учнів, які вивчають географію (28 \%). Серед міст обласного значення за часткою учнів, які вивчають географію, виділяються Дрогобич (3,8 \%) і Червоноград (3,3\%).

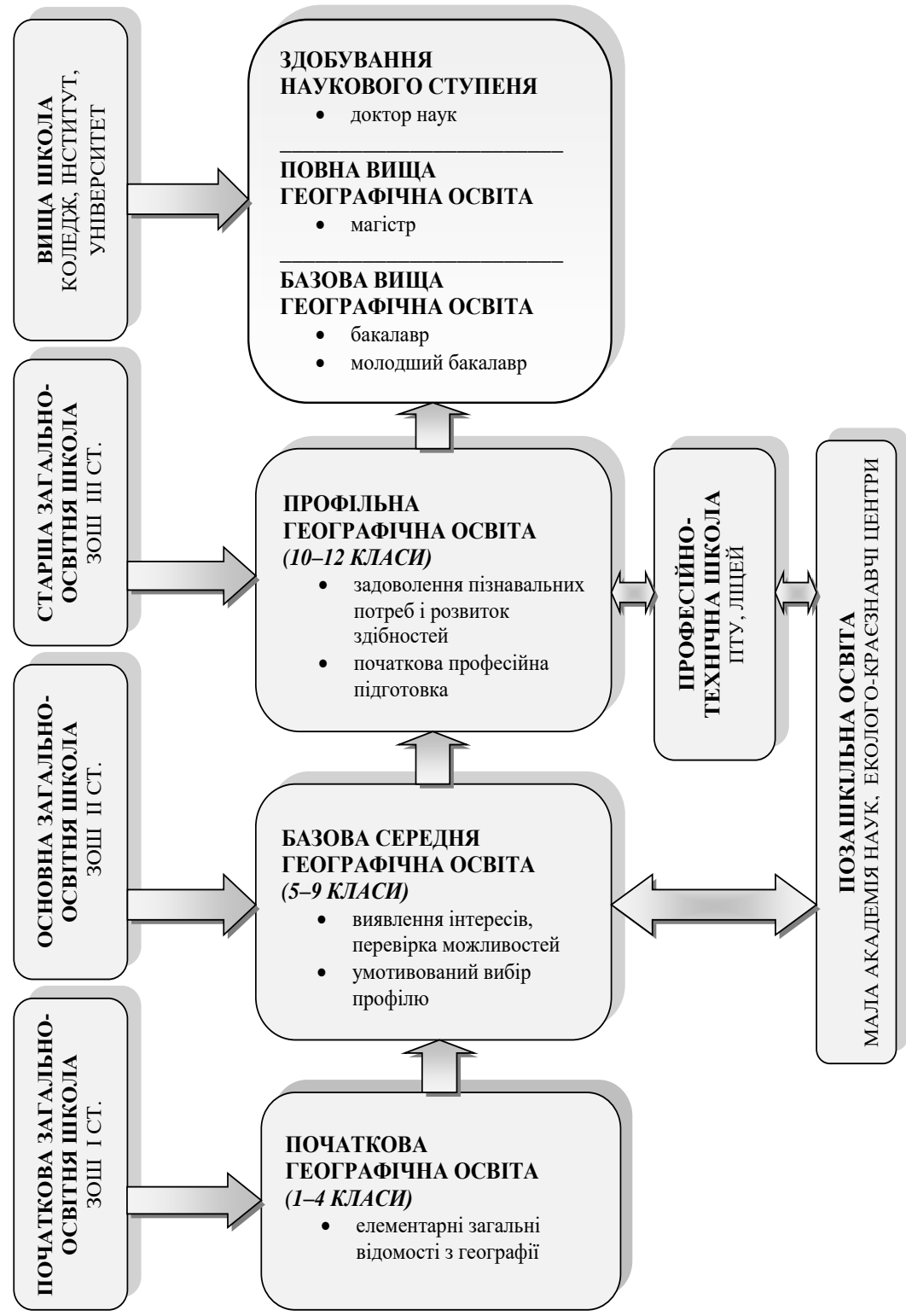

Рис. 1. Структура географічної освіти 
Серед адміністративних районів найбільше основних і повних середніх шкіл у Старосамбірському (64) Жидачівському і Яворівському (62), Пустомитівському (56) районах, найменше - у Миколаївському (32) і Кам'янка-Бузькому (30). Частка учнів-географів найвища у районах, що межують з обласним центром: на Яворівський р-н припадає $6 \%$, на Жовківський - майже $5 \%$, на Пустомитівський - $4 \%$. Найменше школярів-географів у Перемишлянському р-ні $(1,6 \%)$ (рис. 2$)$.

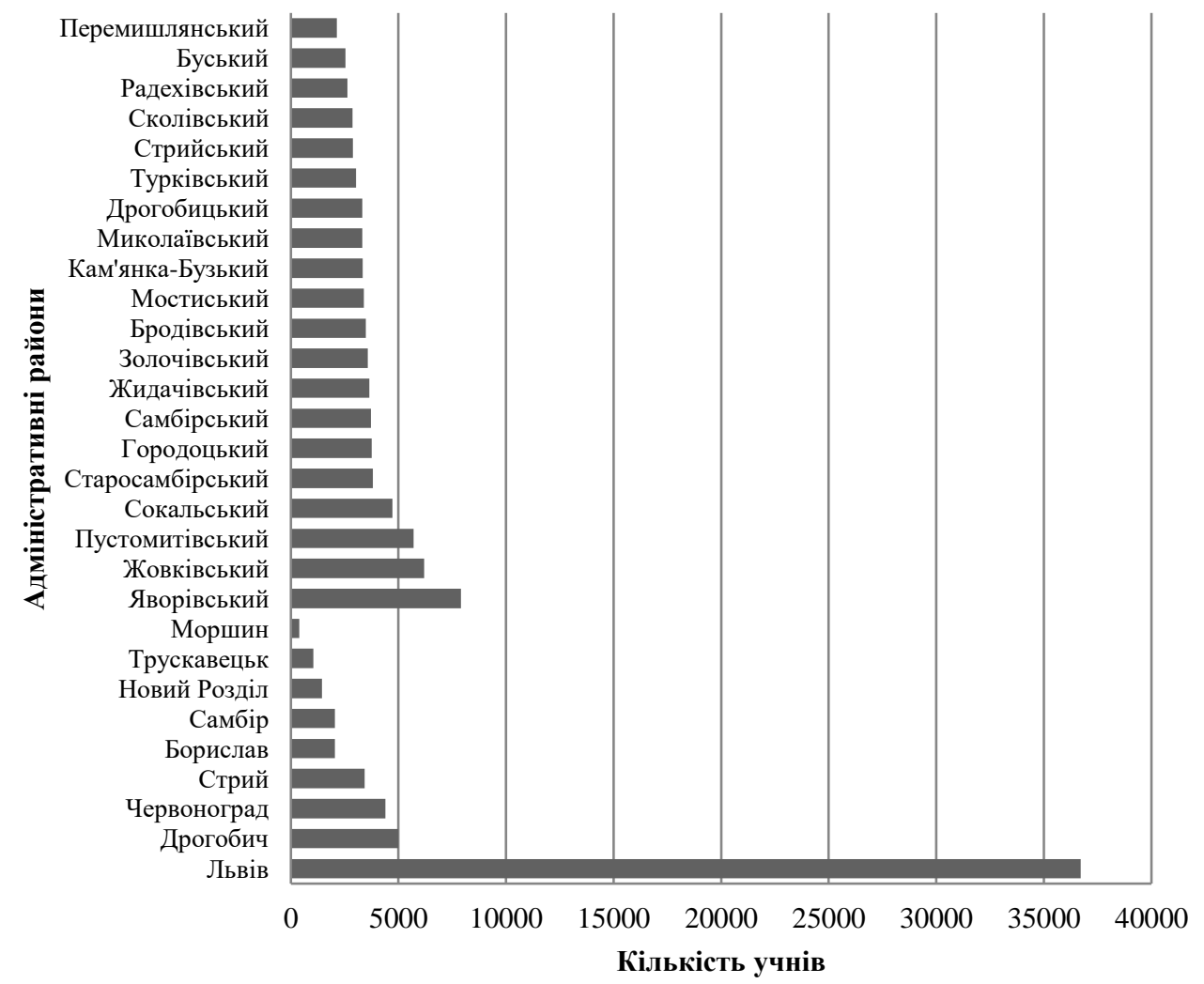

Рис. 2. Територіальний розподіл учнів області, які вивчають географію, 2015/2016 н. p.

Кількісні параметри двох суб'єктів навчального процесу - учителів та учнів - можуть суттево впливати на форму організації навчання. Тому розглянемо ї детальніше. 3 огляду на багаторічну тенденцію скорочення учнівського контингенту (порівняно 32000 p. кількість школярів в області зменшилась на $35 \%$ ) важливим показником $€$ наповнюваність класів.

Середню кількість учнів у класі, який вивчає географію, можна обчислити, з'ясувавши кількість учнів, яка припадає на одного вчителя географії. Наприклад, в обласному центрі та у містах обласного значення на одного вчителя географії припадає 180-190 учнів, тобто у кожному з шести класів, які вивчають природознавство і географію, у середньому є 30 та більше учнів. Винятково велика кількість учнів 278 - припадає на одного вчителя-географа у місті Дрогобич. Такий показник, очевидно, 
$\epsilon$ наслідком не максимально великих класів, а викладання географії вчителями інших дисциплін, яких готує Дрогобицький педагогічний університет.

У школах “сільських” районів - Жидачівського, Радехівського, Старосамбірського кількість учнів на одного вчителя-географа найнижча - 60-70 осіб, тобто у кожному класі приблизно 10-12 учнів. У таких класах та ще й за умов слабкої технологічної бази сільських шкіл методично складніше організувати навчання географії, застосувати сучасні інтерактивні технології. До того ж, у малокомплектній школі практично нівелюється конкуренція між учнями, що ускладнює мотивування навчання.

У найближчі п'ять років у більшості адміністративних районів області кількість учнів на одного вчителя географії, а водночас і наповнюваність учнівських класів зменшиться. Найгіршу перспективу мають Мостиський, Перемишлянський, Сколівський райони.

Нині найменш прогнозованим у кількісному і якісному вимірах $є$ вивчення географії у старшій загальноосвітній школі, яка 3 2016/2017 н. р. повністю переходить на профільне навчання. Потенційні можливості географії на цьому рівні середньої освіти непогані: як профільний предмет їі можуть вивчати у школах 3 природничо-математичним і суспільно-гуманітарним напрямами, окрім того, як у цих школах, так і в освітніх закладах технологічного, художньо-естетичного, спортивного напрямів профілізації можливі елективні географічні курси (курси за вибором), адже сучасна географічна наука має чимало суміжних напрямів i, відповідно, цікавих спецкурсів: "Географія культури", “Медична географія”, “Географія спорту”, “Географія туризму” тощо. Наразі немає вірогідної статистики щодо кількості учнів, охоплених профільним вивченням географії, оскільки перехід до профільного навчання не завершений.

Профілізація старшої школи зумовлює і суттєві зміни в організації функціонування мережі загальноосвітніх закладів, зокрема в сільській місцевості. У 2015/2016 н. p. завершується формування освітніх округів навколо опорних шкіл, на базі яких відбуватиметься профільне навчання. Сьогодні в області існує 116 освітніх округів і процес їхнього формування, який включає правові, фінансові, організаційні аспекти, триває.

Результатом процесу вивчення географії є предметні компетентності учнів. Якість знань і вмінь з географії школярів Львівщини, як і українських школярів загалом, залишається поза увагою вітчизняного освітнього моніторингу. Закриті для освітян та громадськості і результати Міжнародного дослідження якості природничо-математичної освіти TIMSS (Trends in International Mathematics and Science Study) за 2011 р., які проводила ця організація в усіх областях України. Відомо, що географія в тесті з природничих дисциплін цього дослідження займала $20 \%$ (35\% завдань були 3 біології, $20 \%$ завдань - 3 хімії, $25 \%$ - 3 фізики).

Оцінити старання школярів Львівщини у вивченні географії можна тільки серед тих учнів, які ії добре знають, а тому є учасниками різних турів Всеукраїнської олімпіади 3 географії, а також серед тих, хто проходить випробовування з цього предмета на зовнішньому незалежному оцінюванні (ЗНО). Серед українських школярів вихідці з Львівщини мають високі показники: упродовж 2011-2015 pр. школярі області були призерами четвертого туру Всеукраїнської олімпіади з географії (окрім 2014 р.), а у 2015 р. учень Львівського фізико-математичного ліцею Богдан Лущик отримав диплом другого ступеня у конкурсі дослідницьких проектів на Міжнародній олімпіаді з географії, яка відбувалася в Бразилії. 
Третій тур Всеукраїнської олімпіади з географії, який щороку виявляє найобізнаніших і найздібніших юних географів в області, упродовж 2011-2015 рр. дав 42 переможці. Більше половини з них (23 учні) навчались у школах та гімназіях Львова, у тому числі 17 - у гімназії “Престиж”.

Лише трьом сільським учням вдалось у ці роки здобути перемогу на обласній олімпіаді з географії, а учениця Глинського НВК (Жовківський р-н) Соломія Гудз отримала диплом першого ступеня тричі - навчаючись у 9, 10 та 11 класах. Найчастіше перемагали в обласній олімпіаді з географії (2011-2015) учні з Шевченківського та Залізничного районів м. Львова, Яворівського, Жовківського районів та міста Червонограда.

Адміністративні райони і школи, з яких учні найчастіше перемагали в обласних олімпіадах $з$ географії (2011-2015)

\begin{tabular}{|c|c|c|c|}
\hline $\begin{array}{c}\text { Адміністративний район, } \\
\text { школи }\end{array}$ & $\begin{array}{l}\text { Кількість призерів } \\
\text { обласної олімпіади }\end{array}$ & $\begin{array}{c}\text { У тім числі дип- } \\
\text { ломів першого } \\
\text { ступеня } \\
\end{array}$ & $\begin{array}{c}\text { Учителі } \\
\text { географії }\end{array}$ \\
\hline І. Львів. Шевченківський район & 39 & 19 & \\
\hline Гімназія "Престиж" & 18 & 17 & Л.А.Куляба \\
\hline СЗШ № 54 & 9 & 2 & М. С. Герцюк \\
\hline СЗШ № 91 & 4 & 1 & Л. М. Хомин \\
\hline II. Львів Залізничний район & 28 & 4 & \\
\hline $\begin{array}{l}\text { Львівський фізико- } \\
\text { математичний ліцей-інтернат }\end{array}$ & 11 & 2 & В. Г. Гаврилюк \\
\hline Гімназія "Гроно" & 5 & & Г. І. Попович \\
\hline III. Яворівський район & 28 & 3 & \\
\hline $\begin{array}{l}\text { Яворівська гімназія } \\
\text { імені Осипа Маковея }\end{array}$ & 6 & & Г. Ф. Петришин \\
\hline Шклівська СЗШ & 5 & & Д. І. Пастернак \\
\hline Новояворівська СЗШ № 2 & 4 & & М. П. Процик \\
\hline IV. Жовківський район & 20 & 4 & \\
\hline Глинський НВК & 4 & 3 & 3. В. Боровець \\
\hline Замківська СЗШ & 3 & & С. М. Качмар \\
\hline Дублянська СЗШ & 3 & & К. Д. Антонів \\
\hline Рава-Руська СЗШ № 1 & 3 & & О. М. Гореча \\
\hline V. Червоноград & 22 & 2 & \\
\hline Червоноградська СЗШ № 4 & 4 & 1 & Г. Й. Антонів \\
\hline Червоноградська СЗШ № 12 & 3 & 1 & М. І. Мельник \\
\hline Червоноградська СЗШ № 13 & 4 & & Н. Р. Дзіковська \\
\hline Червоноградська гімназія & 4 & & Н .І. Киричук \\
\hline
\end{tabular}

Щороку понад чотири тисячі випускників з Львівщини беруть участь у ЗНО з географії і за кількістю учасників у незалежному тестуванні з цього предмета область належить до четвірки лідерів (разом з Харківською, Дніпропетровською та Київською зі столицею включно). Рейтингові бали з географії на ЗНО випускників з Львівщини вищі від загальноукраїнських. У 2014/2015 н. р. Львівщина посіла перше місце за результатами ЗНО з географії. 
Результати незалежного тестування за 2011-2015 рр. ми проаналізували за такими категоріями випускників, які є на сайті Українського центру оцінювання якості знань: загальноосвітні школи, гімназії, спеціалізовані школи, ліцеї (див. рис. 3-6).

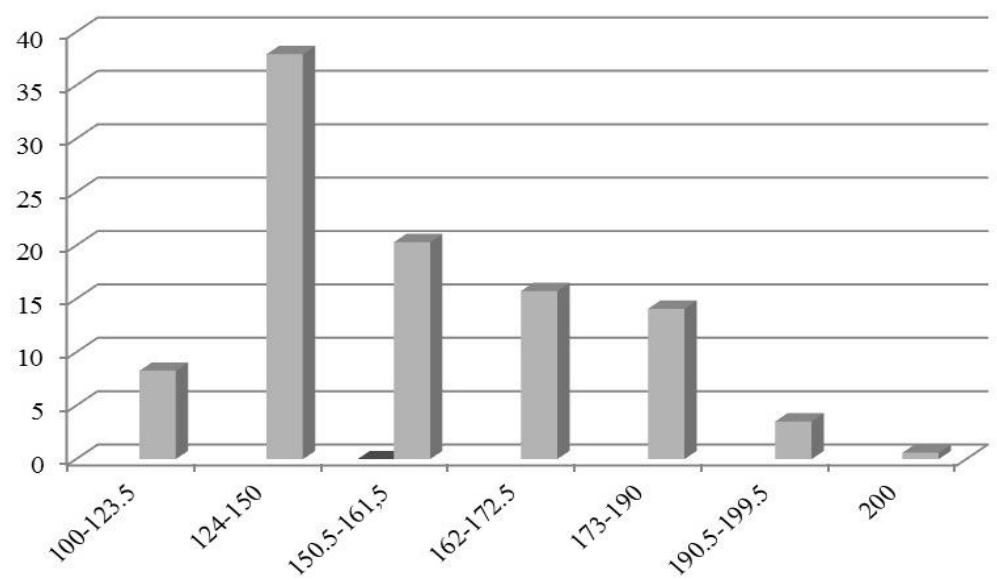

Рис. 3. Частка рейтингових балів з географії, отриманих на ЗНО випускниками загальноосвітніх середніх шкіл області (сумарно за 2011-2014рр.)

Найчастіше учні загальноосвітніх шкіл отримують на ЗНО рейтинговий бал у проміжку від 124 до 150 (38 \%). Лише п’ята частина мають бали 150-162. Найвищі здобутки на ЗНО в цей період продемонстрували школярі зі Сихівського р-ну (майже 43 \% 3 них мали рейтингові бали у проміжку 162-199,5 і два школярі - максимальні 200 балів), а також випускники середніх шкіл Галицького і Франківського районів Львова (їхня частка у цьому проміжку рейтингу - 41 \%). За чотири роки тільки дев'ять учнів загальноосвітніх шкіл мали 200 рейтингових балів, причому чотири з них були зі Стрия, Червонограда, Золочева і Самбора.

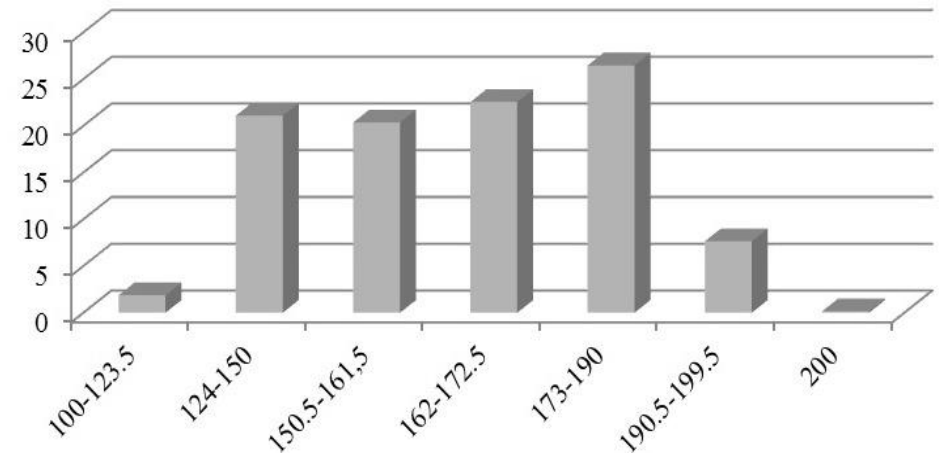

Рис. 4. Частка рейтингових балів з географії, отриманих на ЗНО випускниками гімназій області (сумарно за 2011-2014рp.)

Картина розподілу рейтингових балів гімназистів обернено симетрична порівняно зі школярами: бали гімназистів удвічі рідше, ніж у школярів, потрапляють у проміжок до 150, водночас гімназисти отримують удвічі частіше від школярів високі рейтингові 
бали - від 173 і вище. Якщо підсумувати частку балів від 162 і вище, то можна виділити п'ять гімназій області, учні яких за останні чотири роки отримали найвищий рейтинг 3 географії: Дрогобицька (77 \%), Бориславська (68 \%), Червоноградська (66 \%), гімназії Шевченківського (65 \%) і Франківського (63 \%) районів м. Львова. Високий рівень знань гімназистів не тільки з обласного центру, а й з інших міст свідчать про значний радіус поширення якісного рівня викладання географії в області.

Розподіл рейтингових балів серед школярів спеціалізованих шкіл приблизно такий, як серед випускників найліпших загальноосвітніх шкіл: частка балів від 162 і вище понад $40 \%$, та водночас вона значно нижча, ніж у гімназистів (57 \%).

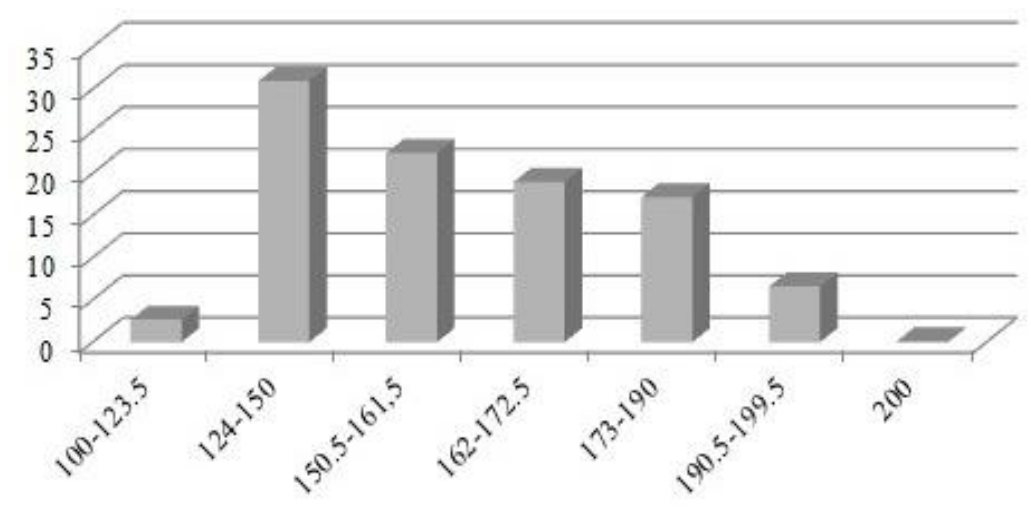

Рис. 5. Частка рейтингових балів з географії, отриманих на ЗНО випускниками спеціалізованих загальноосвітніх шкіл області (сумарно за 2011-2014рр.)

Ліцеїсти складають географію на ЗНО приблизно так само, як учні спеціалізованих шкіл. Винятком є учні Львівського фізико-математичного ліцею, яким належить абсолютна першість в області на незалежному оцінюванні знань 3 географії. Вище 162 балів за 2011-2014 pр. отримали $82 \%$ його випускників, у тім числі $28 \% 3$ них - понад 190 балів.

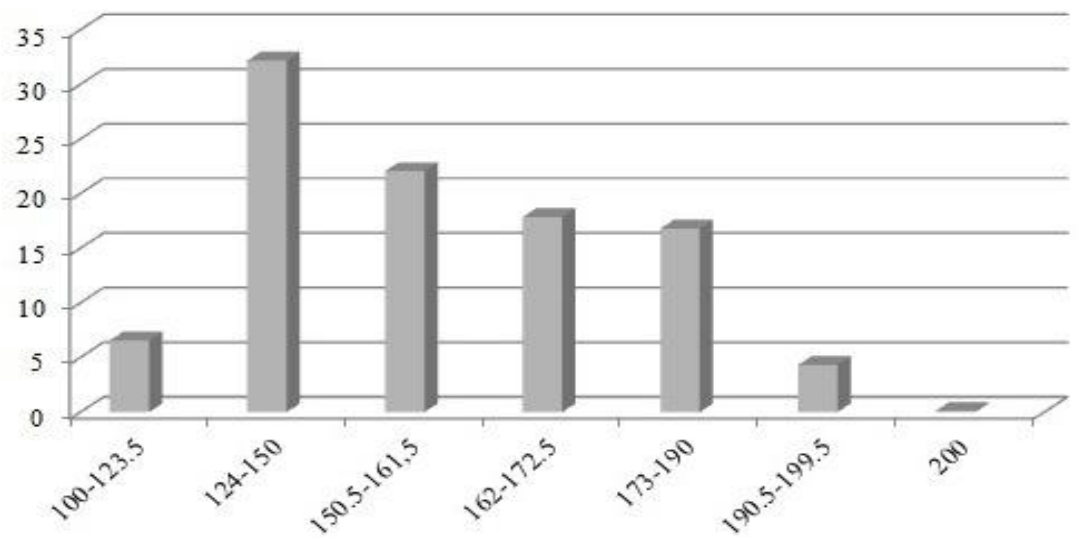

Рис. 6. Частка рейтингових балів з географії, отриманих на ЗНО випускниками ліцеїв області (сумарно за 2011-2014рр.) 
Вивчення географії в школах регіону організовує 1101 педагог-фахівець (5 \% від усіх вчителів регіону), проте у частині шкіл цей предмет викладають і нефахівці. Водночас учителі-географи викладають у школі й інші предмети: насамперед економіку, часто історію, інформатику тощо. Середній показник кількості вчителів географії на одну школу ілюструє тенденцію до скорочення учнівського контингенту та кількості годин 3 дисципліни. У середньому по області на одну школу не припадає навіть один учительгеограф. У містах обласного значення, за винятком Моршина і Трускавця, школи в середньому мають менше двох географів.

Більше половини вчителів географії - 57 \% - працюють у сільській місцевості.

Найбільший педагогічний потенціал з географії має Львів - тут працюють 192 учителі (17 \% від загальної кількості вчителів географії регіону). В адміністративних районах значний педагогічний колектив географів є на Жовківщині (64 особи) та Яворівщині (77 осіб).

Найвагомішу частку вчителів регіону становлять особи віком 41-50 років (34 \%). Це вік фахової й особистісної зрілості, досвіду ще без професійної втоми. Така частка вчителів віку 41-50 років характерна як для міської, так і для сільської місцевості. П'ята частина вчителів регіону має вік 31-40 років, який $є$ оптимальним для новаторства і професійного розквіту. У сільській місцевості області частка вчителів цієї вікової категорії дещо вища, ніж у містах - 23 проти $19 \%$ (рис. 7).

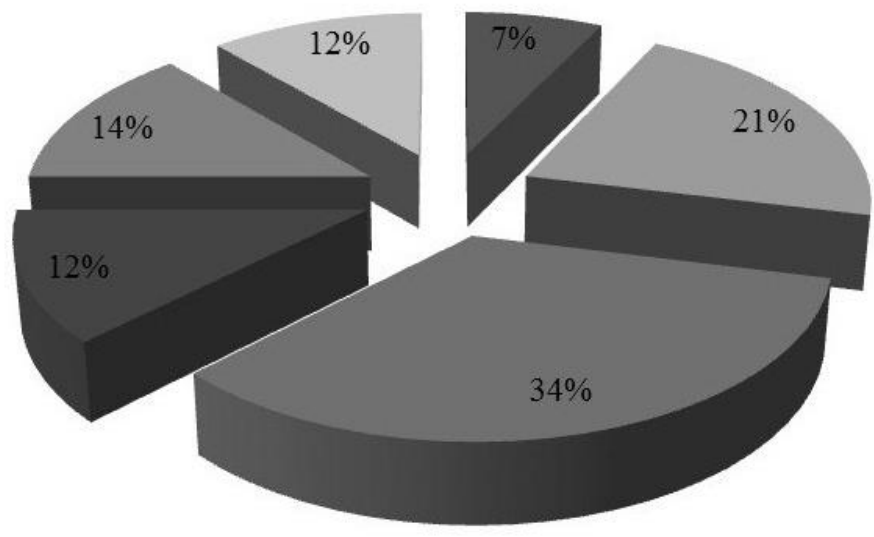

до 30 років

- 31-40 років

41-50 років

- 51-54 років

- 55-60 років

60 і більше

Рис. 7. Розподіл учителів географії за віком

Четверта частина вчителів-географів області мають вік 51-60 років. У містах області вчителів передпенсійного віку значно більше, ніж у селах - 30 проти $23 \%$.

Частка вчителів, які продовжують працювати в школі після виходу на пенсію (вік понад 60 років), становить приблизно $12 \%$ і є однаковою як для сільської, так і для міської місцевості. Станом на 2015/2016 н. р. у школах області працює 127 учителів віком понад 60 років (56 осіб у містах і 71 у селах).

Найбільше потребуватимуть припливу молодих фахівців школи Львова (38 учителів передпенсійного і пенсійного віку), Жовківського (14), Пустомитівського (11), Радехівського (11), Самбірського (11), Турківського (11), Старосамбірського (10) районів (див. рис. 8,9 ). 


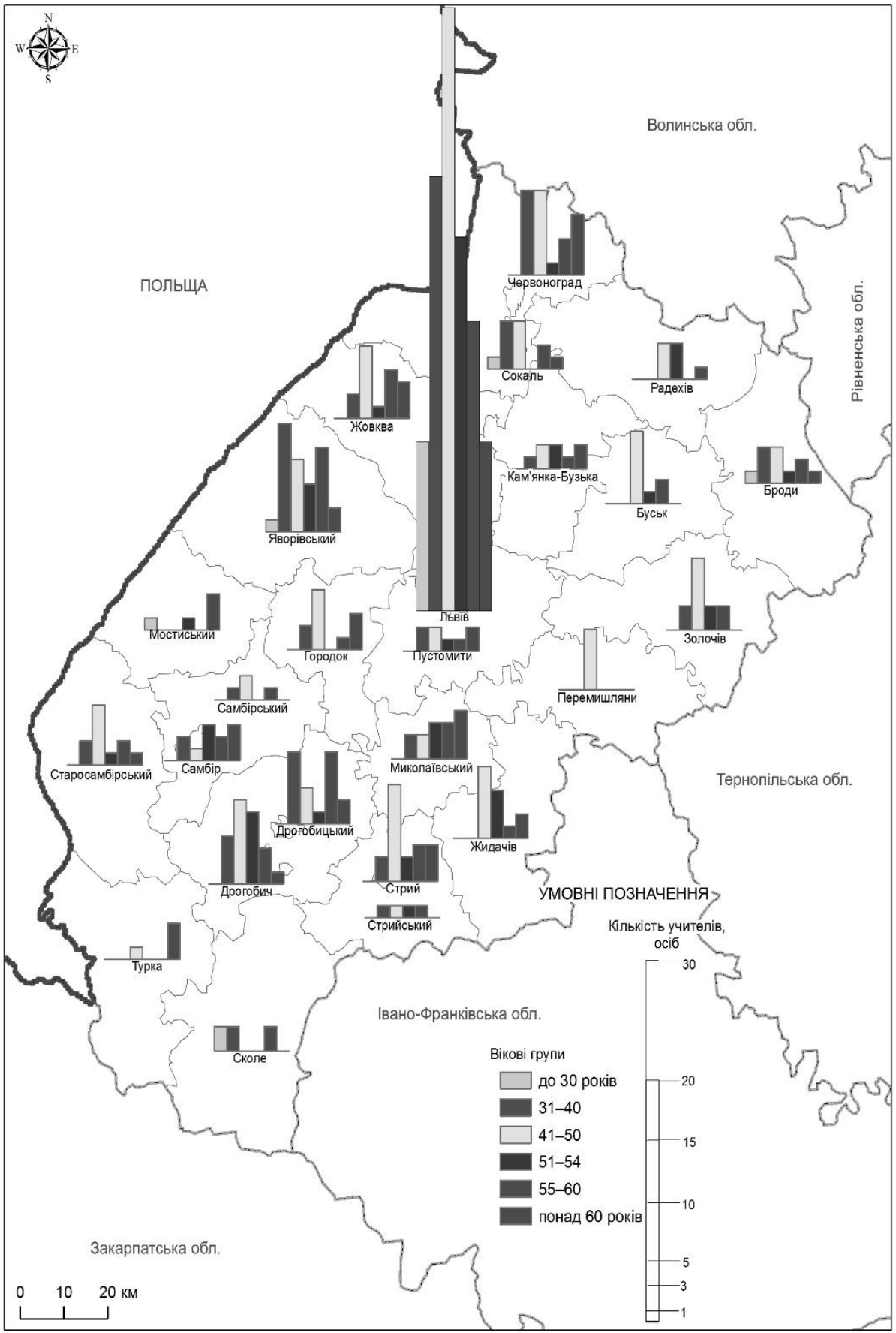

Рис. 8. Розподіл учителів географії за віком у міських школах Львівської обл. 


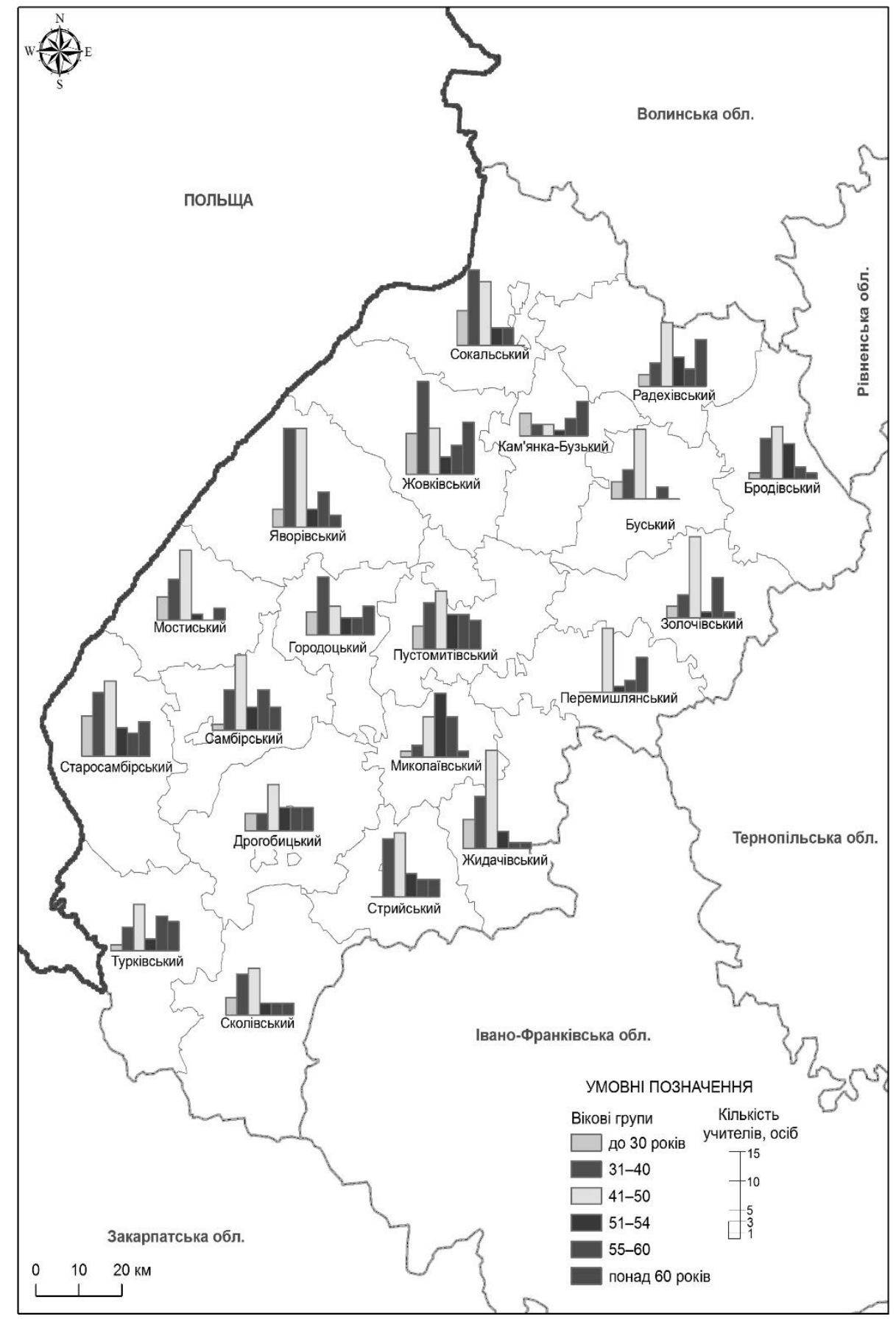

Рис. 9. Розподіл учителів географії за віком у сільських школах Львівської обл. 
Найстарша за віком категорія учителів географії є численнішою, ніж наймолодша верства учительства (віком до 30 років): в області загалом працює лише 7 \% учителівгеографів цього віку. У містах їх ще менше - 4 \%. У 20 міських поселеннях області в школі немає жодного молодого вчителя географії. У селах регіону молодих учителів дещо більше - майже 10 \%. Через низьку оплату вчительської праці ця професія є малопривабливою для молодих спеціалістів, які воліють працювати не за фахом, проте за більшу зарплату. I тільки в сільській місцевості за гірших можливостей працевлаштування вчительські вакансії молоді фахівці займають охочіше.

Учителі географії Львівщини плідно працюють у різних напрямах сучасних технологій навчання. Ефективною реалізацією компетентнісного підходу у навчанні географії засобами краєзнавства і туризму відомі такі вчителі-методисти: Анатолій Васильович Люсак (Жидачівська гімназія), Зоряна Володимирівна Боровець (Глинський НВК, Жовківський р-н), Олег Степанович Крисюк (класична гімназія, м. Львів), Мар'яна Іванівна Ліщинська (Новокропивницька ЗОШ, Дрогобицький р-н); використанням елементів емпауермент педагогіки на уроках географії - Анжела Петрівна Дроняк (ЗОШ № 41, м. Львів); застосуванням сугестивної педагогіки у навчанні географії - Любов Володимирівна Сура (Нововиднівська ЗОШ, Радехівський р-н); досконалим методичним рівнем організації активного навчання - Марія Миколаївна Пац (Добросинська ЗОШ, Жовківський р-н), Наталія Миколаївна Косик (ЗОШ с. Старичі, Яворівський р-н), Василь Васильович Шипівдич (гімназія м. Новий Розділ), Ярослав Михайлович Стецишин (ЗОШ № 2, смт Красне), Ірина Петрівна Гораєцька (Буська гімназія імені Є. Петрушевича при Львівському національному університеті імені Івана Франка), Наталія Степанівна Цуп (Червонянська ЗОШ, Золочівський р-н), Марія Василівна Носовська (Самбірська ЗОШ).

Двоє вчителів області - Лариса-Леся Андріївна Куляба (учителька географії львівської гімназії “Престиж”) та Ярослав Михайлович Пилипів (учитель географії гімназії ім. митрополита Андрея Шептицького, м. Стрий) удостоєні звання “Заслужений учитель України".

Учителі географії області мають вагомий дослідницький доробок у галузі краєзнавства, результатом якого є публікація таких краєзнавчих підручників, посібників і навіть атласів: Івашків Я. М. Миколаївське Придністров'я, 1993; Івашків Я. М., Івашків К. В. Миколаївський район. Атлас, 1998; Стецишин Я. П. Бузеччина, 1997; Сліпець С., Скіра О. Жовківщина, 1998; Богдан Я. Я. Золочівщина, 1999; Стасюк І. І. Сокальщина, 1999; Сакаль Є. В. Географія Стрийщини, 1999; Максименко В. Ф. Географія Кам'янеччини, 2001; Калита Н. Й. Географія Мостиського району, 2002; Андрейко I. М. Природа Городоччини, 2002; Береза В. Старосамбірщина, 2002; Бухней Я. Й., Крисюк О. С. Львів: географія фізична та історична, екологія, 2002; Бухней Я. Й., Крисюк О. С. Мандрівки на природу Львова, 2003; Когут Н., Партем К. Моя Пустомитівщина, 2003; Турченяк Я. Краєзнавчі матеріали про природу та річкову мережу Жидачівщини, 2004; Сліпець С. та ін. Туристськими шляхами Жовківщини. Путівник, 2005; Машура Г. та ін. Самбір і Самбірщина, 2005; Зинів Г. М. Природа Дрогобиччини, 2008; Іванчишин Л. П. Перемишлянщина, 2008; Косик Н., Косик Л. Скарби Яворівщини, 2009; Зинів Г. М., Зінкевич М. В. Населення і господарство Дрогобиччини, 2010; Лоза Б. О. Природа Брідщини, 2010; Костишин Е. Краєзнавчі розмаїтості Новорозділля, 2013; Господарство Яворівщини. Інформаційний довідник для вчителів загальноосвітніх закладів, 2015, укладений творчим колективом учителів географії району. 
Унікально багатогранними є краєзнавчі пошуки відомого на Турківщині вчителя географії і директора Лімнянського НВК Ярослава Тирика, який опублікував чимало грунтовних етногеографічних досліджень Бойківщини: Турківщина, 2000; Дорогами і стежками Івана Франка. Мандрівки Галичиною, 2002; Золоте кільце Бойківщини. Мандрівки Галичиною, 2003; Руський путь - прадавній шлях через Карпати, 2003; Рідний край. Турківщина, 2005.

Реалізації краєзнавчого підходу у шкільній географії сприяє авторська творча майстерня вчителів географії, до складу якої входить 14 учителів з області (керівник - К. Партем, координатор - М. Зінкевич). Вони об’єднують зусилля з вивчення та підготовки до друку нових посібників з географії рідного краю. Комплексний навчальний посібник “Географія рідного краю. Львівська область" (2011) написав старший викладач кафедри природничо-математичної освіти ЛОІППО Мирослав Зінкевич.

Географія у системі профтехосвіти. До 2016/2017н. р. географію вивчають і в професійно-технічних навчальних закладах та ліцеях. Однак тільки 65 \% учнів ПТУ здобувають разом з професією повну загальну освіту. Тому приблизна кількість учнів, які вивчають географію як предмет, що є базовим для середньої освіти, становить такий же ж відсоток, або понад 11 тис. осіб. Навчання предмета організовує майже 60 учителів. Незважаючи на те, що з 2016/2017 н. р. географію як предмет не викладатимуть у ПТУ, профільне навчання дає змогу впроваджувати відповідно до обраного напряму елективні географічні курси. I все ж для педагогічних працівників професійно-технічних навчальних закладів, як і для інтенсивно реформованих вищих навчальних закладів I-II рівнів акредитації (технікумів, коледжів) “перехід” географії в базову школу позначиться значним звуженням поля викладацької діяльності.

Позашкільна географічна освіта. Мала академія наук, еколого-туристичні центри й інші позашкільні структури відіграють вагому роль у популяризації географічної освіти серед шкільної молоді, у допрофільному та профільному вивченні цього предмета. У структурі Львівської обласної Малої академії наук учнівської молоді діє відділення наук про Землю, у якому дистанційно та очно навчаються учні 9-11 класів усього 182 особи, з якими працюють два географи-викладачі. Наукові товариства МАН діють у Бродах, Золочеві, Стрию, Самборі та Львові. Мала академія робить значний внесок у поглиблення географічних знань серед школярів (всеукраїнські турніри юних географів) та у формування дослідницьких навиків серед старшокласників: під керівництвом викладачів географічного факультету ЛНУ імені Франка студенти МАН пишуть дослідницькі проекти.

Вища географічна освіта в регіоні. На території області здобути вищу географічну освіту можна у двох вищих навчальних закладах: на географічному факультеті Львівського національного університету імені Івана Франка - одному з найстаріших географічних факультетів України, та на створеній у 2014 р. кафедрі екології та географії Дрогобицького державного педагогічного університету імені Івана Франка. Львівщина - друга область в Україні після Київської, де фах географа можна здобути як у класичному, так і в педагогічному університетах. Сьогодні триступеневу вищу географічну освіту забезпечує тільки класичний університет, у якому діють сім кафедр географічної спеціалізації, на яких працюють 82 викладачі-науковці.

Станом на 2014/2015 н. р. вищу географічну освіту в області здобували 890 студентів денної і заочної форм навчання у Львівському національному університеті імені Івана 
Франка і 22 студенти денної форми навчання в Дрогобицькому державному педагогічному університеті імені Івана Франка.

Популярність вищої географічної освіти в області, попри вузький ринок праці для фахівців з географії, спонукала нас до детального вивчення місця походження студентів, їхного ставлення до праці в освітній галузі, мотивації вступу і намірів щодо працевлаштування після закінчення університету, власної оцінки вагомості здобутої ними географічної освіти. Відповіді на ці питання з'ясовано через анкетування 131 випускника географічного факультету ЛНУ імені Івана Франка 2015/2016 н. р. та вивчення особових справ студентів факультету географічної спеціалізації обох форм навчання.

Основна частина студентів (75\%) - вихідці з Львівської обл., 20 \% приїхали навчатись з сусідніх областей: Волинської, Рівненської, Тернопільської, Івано-Франківської, Закарпатської (серед них найбільше - з Волинської та Івано-Франківської). 3 інших областей України навчається 5 \% студентів, причому половина 3 них прибула 3 областісусіда другого порядку - Хмельницької (рис. 10).

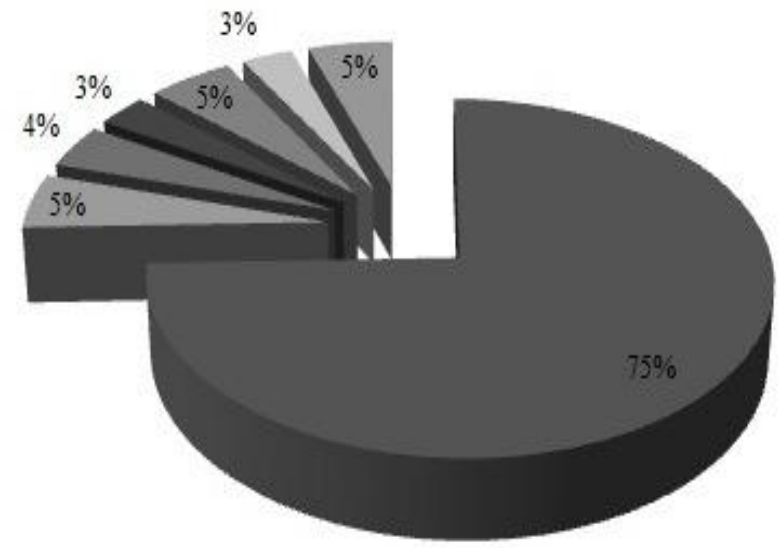

\author{
- Львівська обл. \\ шолинська обл. \\ Фівненська обл. \\ - Тернопітьська обл. \\ пІв.-Франківська обл. \\ "Закарпатська обл. \\ шнші області Україн
}

Рис. 10. Місце походження студентів-географів ЛНУ імені Івана Франка

Детальніший аналіз географії походження студентів засвідчує що, окрім територіальної близькості, на частку студентів з тієї чи іншої місцевості впливає кількість учнів у ній. Наприклад, найбільше студентів на факультеті - 190 осіб, або $30 \%$ - мають львівське походження. У розрізі адміністративних районів найчастіше на факультет вступають випускники 3 Жовківського та Пустомитівського районів (приблизно по тридцять студентів 3 кожного), які мають найчисленніший учнівський контингент. По два десятки студентів навчається з багатих на учнів, але більш віддалених від Львова Сокальського, Старосамбірського і Яворівського районів. Лише кілька осіб здобуває вищу географічну освіту з демографічно депресивного Перемишлянського р-ну, а також віддалених і нечисленних щодо учнів Бродівського і Сколівського районів.

Якість знань з географії випускників шкіл, яку забезпечують, або належна методична школа викладання, або наявність кваліфікованих репетиторів також має вплив на географію вступників. Зокрема серед львів'ян найбільше студентів-географів серед випускників п’яти шкіл: гімназії “Престиж” (вісім осіб), ЗОШ № 46 і 91 (по сім осіб), гімназій “Гроно” і “Сихівська” (по п’ять осіб). 
3 усіх студентів-географів тільки $14 \%$ закінчили спеціалізовані школи чи гімназії, причому ця частка значно зростає серед тих, хто приїхав навчатись 3 інших областей України: серед студентів зі Львова вона становить $19 \%$, з Волинської обл. - $21 \%$, а $з$ областей не сусідів Львівщини $-36 \%$.

Фах географа здобувають головно дівчата (75 \% від усіх студентів) і переважно мешканці міст $(65 \%)$.

Наміри щодо працевлаштування, сфери праці в студентські роки й оцінка вагомості здобутої освіти були з'ясовані окремо серед студентів-магістрів і спеціалістів.

Серед магістрів тих, хто вже працює в галузі освіти (неповне навантаження) або впевнений, що буде прийнятий на викладацьку роботу, - тільки $6 \%$. Усі вони - дівчата з сільської місцевості. Ще 19 \% п’ятикурсників-магістрів (винятково дівчата, які головно проживають у містах) хочуть працювати в школі, але сумніваються, що знайдуть вільну вакансію. Такій же ж частині випускників професія вчителя до вподоби, проте через низьку зарплату вони не мають наміру працювати в школі. Ще $17 \%$ припускає, що можливо життєві обставини змусять їх працювати в школі. Серед цієї групи респондентів більше третини - чоловіки міського та сільського походження. Дехто припускає, що працюватиме в освітній галузі, але не за спеціальністю (4 \%). Отже, загалом серед магістрів $65 \%$ випускників потенційно зорієнтовані на працю в освітній галузі, проте через об'єктивні причини навряд чи там опиняться.

За роки навчання $11 \%$ студентів, які також були зорієнтовані на викладання географiї в школі, зрозуміли, що це не їхнє покликання. Частка тих, які виключають працю в галузі географічної освіти, невисока $(13 \%)$ : за жодних умов не підуть працювати в освітні заклади $4 \%$, ще $9 \%$ ніколи про це не мріяли. Отже, негативне ставлення до географічної освіти як сфери прикладання праці мають майже чверть магістрівгеографів. Приблизно десята частина випускників цього освітньо-кваліфікаційного рівня бачить себе в туристичній галузі.

Серед випускників-спеціалістів працівників в освітній галузі трохи більше - $9 \%$, однак порівняно з магістрами переважають міські дівчата. Частка респондентів-спеціалістів, які хочуть працювати в школі, але сумніваються у наявності вакансії, дещо нижча, ніж у магістрів - $17 \%$, та, на відміну від них, про таке мріють винятково сільські дівчата. Ще $13 \%$ хотіли б працювати в школі, але низька зарплата стримує їхні пошуки роботи в цій сфері. Більше чверті опитаних (27 \%) припускають, що залежно від життєвих обставин, можливо, таки влаштуються в школу (серед них - 6 \% міських студентівчоловіків). Це значно вищий показник, ніж у магістрів. Так само, як і в магістрів, 4 \% (винятково хлопці) припускають, що працюватимуть в освітній галузі, проте не за спеціальністю.

Отже, серед випускників-спеціалістів на працю в освітній галузі зорієнтовано $70 \%$ студентів, що на п'ять пунктів більше, ніж серед магістрів.

Категорично проти праці в освітній галузі $27 \%$ опитаних: $19 \%$ ніколи про це не мріяли (серед магістрів таких було на шість пунктів більше), 6 \% мріяли, але розчарувались у привабливості педагогічної праці, 2 \% бачить своє професійне майбутнє у сфері туризму. Отже, серед випускників-спеціалістів противників освітянської кар'єри менше на шість пунктів порівняно з магістрами.

Студенти-випускники по різному оцінюють свої шанси влаштуватись в інші, ніж освіта, сфери зайнятості. Для $21 \%$ магістрів це питання є дуже болючим. Проблема працевлаштування найбільше хвилює тих дівчат-магістрів (як міських, так і сільських), які 
б хотіли працювати в школі: саме вони не уявляють, де шукати роботу після закінчення факультету. Близько 17 \% випускників розважливо ставляться до проблеми майбутнього працевлаштування, а $13 \%$ про це ще не задумувались. Водночас стільки ж $(13 \%)$ студентів-магістрів уже знайшли роботу і мають намір працювати на тому ж місці після закінчення навчання; 15 \% від опитаних мають намір шукати місце праці за кордоном.

Випускники-спеціалісти, які зазвичай віддають навчанню менше часу, ніж магістри, проблему працевлаштування вирішують більш кардинально: 23 \% уже працюють і мають намір залишитись на цьому ж місці після закінчення університету (серед магістрів таких менше на десять пунктів), причому серед зайнятих майже немає сільських мешканців. Для $23 \%$ спеціалістів питання працевлаштування є дуже болючим і серед них переважають студенти сільського походження. Ще $19 \%$ оптимістично налаштовані "якусь роботу знайдуть". Тих, які ще не думають про роботу - 9\%, а $17 \%$ опитаних мають намір шукати місце праці за кордоном.

Незалежно від професійних уподобань студенти п'ятого курсу намагаються працювати, щоб утримати себе чи навіть оплачувати власне навчання. Серед магістрів частка тих, хто працює, становить $53 \%$. Респонденти цього освітнього рівня назвали різні сфери зайнятості: переважно це торгівля ( $19 \%$ зайнятих), маркетинг і менеджмент (11\%), транспорт і логістика (6\%), туризм і сфера послуг (3\%). Є зайняті і в таких напрямах, як аутсорсинг, хендмейд.

Серед спеціалістів відсоток частково зайнятих студентів трохи нижчий, ніж серед магістрів і становить $51 \%$. Проте сфери зайнятості ті ж самі: домінує торгівля $(17 \%)$, маркетинг і менеджмент (15\%). Водночас значно вища частка сфери послуг - 17 проти $3 \%$.

Цікавою є оцінка випускниками факультету соціальної і фахової значимості здобутої ними географічної освіти. Серед вибраних магістрами відповідей найчастіше (53\%) траплялась така: отримані знання і досвід знадобляться мені в житті. Такий погляд часто поєднувався зі ще одним висновком: я цікаво і весело провела (провів) п’ять років студентського життя (38\%). Частка тих, хто, окрім цікаво проведеного часу, оцінює навчання ще і як процес здобування фаху, серед магістрів становить $30 \%$. Для ще майже $20 \%$ магістрів навчання на географічному факультеті було своєрідним стартовим майданчиком у світ, адже після закінчення школи вони не знали, яку професію вибрати.

Одиничними були відповіді на кшталт: “я здобула (здобув) диплом про вищу освіту і це все, що мені було потрібно”, “було цікаво, але мушу вчитись далі, щоб отримати більш конкретний фах", "я змарнувала час, бо нічого така освіта мені не дала".

Оцінка вагомості здобутої освіти респондентами-спеціалістами дещо інша: 57 \% уважають, що отримані знання і вміння знадобляться в житті; для $26 \%$ це ще був і весело та цікаво проведений час (серед магістрів таких було на 12 пунктів більше). Усвідомлення здобутого фаху продемонстрували тільки $17 \%$ опитаних (у 1,5 раза менше, ніж серед магістрів), проте серед спеціалістів виявилось менше тих, хто прийшов на факультет через невизначеність щодо професійного майбутнього (13 проти $20 \%)$, однак більше таких, які зізнались, що їм потрібен тільки диплом про вищу освіту (9 \%), і тих, що усвідомили необхідність здобування ще однісї, більш конкретної освіти (4 \%).

Тепер зіставимо наміри випускників факультету і можливості ринку праці в освітній сфері. Як уже зазначено, зважаючи на частку вчителів географії передпенсійного і пенсійного віку, у найближчі п'ять років буде 250-270 потенційних вакансій (якщо вчителі вирішать піти на пенсію). Якщо врахувати частку тих випускників, які хочуть працювати в школі, незважаючи навіть на низьку зарплату (17 студентів з усього курсу, між якими 
майже порівну міських і сільських жителів), то за найближчі п’ять-шість років випускники факультету могли б замінити вчителів пенсійного віку у містах і за сім-вісім років у селах області. У містах це були б вчительки-магістри, у селах - переважно вчителькиспеціалісти.

Науково-методичні зв'язки між ланками географічної освіти регіону. Результативність навчального процесу з географії залежить від інтенсивності кругообігу науковометодичної інформації між науковим закладом (географічний факультет), обласним Інститутом післядипломної освіти, районними і міськими науково-методичними центрами та педагогами-фахівцями.

Підвищення кваліфікації вчителів географії, методичний консалтинг освітніх інновацій, практичну розробку педагогічних проблем забезпечує Львівський обласний інститут післядипломної педагогічної освіти (ЛОІППО), зокрема кафедра природничо-математичної освіти, на якій працюють два викладачі географії. Щороку в ЛОІППО підвищують свою педагогічну кваліфікацію майже 60 учителів географії загальноосвітніх закладів та профтехучилищ.

Науково-інформаційну підтримку вивчення географії в середній ланці освіти певною мірою забезпечує співпраця ЛОІППО і географічного факультету ЛНУ імені Івана Франка. Такі форми співпраці, як заняття науковців з учителями, які підвищують фахову кваліфікацію на курсах, організація і проведення третього етапу Всеукраїнської олімпіади з географії, підготовчі тренінги до четвертого етапу Всеукраїнської олімпіади з географії, участь науковців у семінарах-тренінгах за міжнародним проектом “Освіта для сталого розвитку”, взаємна участь у науково-практичних конференціях, рецензування науково-методичних публікацій викладачів ЛОІППО, допис викладачів-науковців факультету в журнал “Педагогічна думка" сприяють проникненню здобутків географічної науки в шкільне середовище.

Отже, в області завершується формування чотириступеневої системи географічної освіти. На найближчі п’ять років найліпшу перспективу кількісних показників розвитку матиме базова географічна освіта, що зумовлено порівняно сприятливою ситуацією 3 кількістю учнівського контингенту в молодшій школі регіону. Проте в таких районах, як Перемишлянський, Мостиський, Сколівський, кількість учнів, які вивчають географію, зменшуватиметься. Для цього сегмента географічної освіти актуальною є проблема оновлення складу педагогічних працівників молодими вчителями. Найстарші за віком учителі працюють в містах області (окрім обласного центру). У найближчі п'ять років передпенсійного (55-60 років) і пенсійного віку досягне четверта частина вчителів географії області.

Сегмент вищої географічної освіти регіону успішно розвивається завдяки популярності серед абітурієнтів географічного факультету ЛНУ імені Івана Франка і появі ще однієї університетської географічної кафедри - у Дрогобицькому державному педагогічному університеті імені Івана Франка. Склалась суперечлива тенденція між кількісним зростанням професійного сектора географічної освіти та потребами загальноосвітньої школи у фахівцях, між соціально зумовленим обмеженням працевлаштування молодих фахівців і зростанням частки пенсіонерів серед учителів географії. 3'ясовано, що в освітній галузі не проти працювати $65 \%$ студентів-випускників географічного факультету ЛНУ імені Івана Франка, які можуть за п'ять-сім років замінити всіх учителів географії регіону передпенсійного і пенсійного віку. Відсутність ефективної освітньої політики на державному і регіональному рівнях унеможливлює поповнення шкільного 
сегмента географічної освіти молодими фахівцями, що уповільнює процес модернізації освіти і реальне ії реформування.

Найменш прогнозованою у кількісному вимірі є ситуація 3 профільним рівнем вивчення географії в загальноосвітніх та професійно-технічних закладах, а також у вищих навчальних закладах I та II рівнів акредитації (коледжах, технікумах). Цей ступінь географічної освіти потребує подальшого вивчення. Актуальною проблемою для досліджень у цій сфері $є$ і територіальні зміни в освітній мережі, зумовлені переходом до профільної освіти.

\section{СПИСОК ВИКОРИСТАНОЇ ЛІТЕРАТУРИ}

1. Звіт про чисельність і склад педагогічних працівників загальноосвітніх навчальних закладів станом на 1 жовтня 2015 року: Форма № 83-РВК // Департамент освіти і науки Львівської обласної державної адміністрації.

2. Зведений звіт денних загальноосвітніх закладів станом на 5 вересня 2015 року: Форма № 76-РВК // Департамент освіти і науки Львівської обласної державної адміністрації.

3. Протоколи результатів III туру Всеукраїнської олімпіади з географії (2011-2015рр.) // Львівський обласний інститут післядипломної педагогічної освіти.

4. Результати зовнішнього незалежного оцінювання. Регіональні дані. Географія // Український центр оцінювання якості освіти [Електронний ресурс]. - Режим доступу: http//testportal.gov.ua/reports.

5. Шищенко П. Г. Структурні рівні і зміст державних стандартів географічної освіти / П. Г. Шищенко, Я. Б. Олійник, О. Ю. Дмитрук // Україна. Географічні проблеми сталого розвитку: зб наук праць [в 4-х т.]. - К. : ВГЛ Обрії, 2004. - Т. 1. - С. 328.

\section{REFERENCES}

1. Departament osvity $i$ nauky Lvivskoi oblasnoi derzhavnoi administratsii. Zvit pro chyselnist i sklad pedahohichnykh pratsivnykiv zahalnoosvitnikh navchalnykh zakladiv stanom na 1 zhovtnia 201 roku: Forma N 83-RVK.

2. Departament osvity $i$ nauky Lvivskoi oblasnoi derzhavnoi administratsii. Zvedenyi zvit dennykh zahalnoosvitnikh zakladiv stanom na 5 veresnia 2015 roku: Forma N 76-RVK.

3. Lvivskyi oblasnyi instytut pisliadyplomnoi pedahohichnoi osvity. Protokoly rezultativ III turu Vseukrainskoi olimpiady z heohrafii (2011-2015 rr.).

4. Ukrainskyi tsentr otsiniuvannia yakosti osvity. Rezultaty zovnishnoho nezalezhnoho otsiniuvannia. Rehionalni dani. Heohrafiia, available at: http//testportal.gov.ua/reports.

5. Shyshchenko, P. H., Oliinyk, Ya. B., \& Dmytruk, O. Yu. (2004). Strukturni rivni i zmist derzhavnykh standartiv heohrafichnoi osvity. In Ukraina. Heohrafichni problemy staloho rozvytku, 1. Kyiv: VHL Obrii, 328.

Стаття: надійшла до редакиії 15.08.2015 доопрацьвована 17.09.2015 прийнята до друку 15.10.2015 


\title{
GEOGRAPHIC EDUCATION IN LVIV REGION
}

\section{Mariia Lavruk}

Ivan Franko National University of Lviv,

\author{
P. Doroshenko Str., 41, UA-79000 Lviv, Ukraine,
} e-mail:lavruk.maria@gmail.com

\begin{abstract}
In the context of reforming secondary and high school education in Ukraine, the geographic education of the region and the country as a whole should be considered as a system that includes initial, basic, preprofessional and professional level. Currently, there is no overall picture of the status and trends of development of the various segments of geographic education in the Lviv region that are necessary to consider while constructing regional education policy. The article defines quantitative indicators of the subjects of the learning process in geography on various educational levels and in territorial aspect. This study reveals that during next five years, the best prospects regarding quantitative indicators will have basic geographical education, due to relatively favorable situation with the number of pupils in primary schools of the region. The article shows in detail the educational achievements of geography students at regional and national levels; points the centers for optimal development of geographic education such as Lviv, Drohobych, Sambir, Stryi, Chervonograd; and reveals scientific and methodological improvements of teachers of geography in the region. The research analyzes the contradictory trend between quantitative growth of professional sector of geographical education (opening of new regional university departments) and the needs of secondary school in specialists, and between socially conditioned restriction of employment of young professionals because of growing proportion of retired among teachers of geography. It was found that $65 \%$ of graduate students of department of geography at Ivan Franko National University of Lviv do not mind working in education and respectively can replace within 5-7 years all teachers of geography at pre-retirement and retirement age in the region. However, the lack of effective educational policies at national and regional levels prevents replenishment of school's segment of geographical education by young professionals, and thus slows down the process of modernization of education and its real reform.

Key words: geographic education, levels of geographic education, the quality of knowledge on geography, age structure of geography's teachers, teaching achievements of the geography teachers of the region, professional intentions of the graduates of Geography Department.
\end{abstract}

